Ay THE MERSHON CENTER at The Ohio State University

\title{
Phillip Allot
}

Citizenship Speaker Series

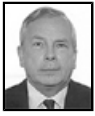

Phillip Allott

Trinity College

"The Globalisation of

Philosophy and the Philosophy of Globalisation"

Tuesday, March 30, 2004

3:30 p.m. *

Mershon Center

Room 120

Philip Allott is a professor of law and a Legal Counselor in the British Foreign and Commonwealth Office, the Legal Adviser to British Military Government in Berlin, and was Legal Counselor in the British Permanent Representation to the European Communities,

Brussels, at the time of British accession to membership of the European Community. He was Alternate Representative in the British delegation to the UN Law of the Sea Conference. He is author of Eunomia - New Order for a New World, a general social and legal theory of international society for the new millennium.

Allot is author of The Health of Nations, which was awared the American Society of International Law's Annual Award in 2003.

He is presently Reader in International Public Law and a Fellow of Trinity College, University of Cambridge. He is also on the Global Law Faculty at New York University School of Law.

*R.S.V.P. to Ann Powers if you plan to attend this event. 